\title{
PROBLEMATIKA PENGGUNAAN DESAIN INDUSTRI PADA ALAT MUSIK TRADISIONAL
}

\author{
Budi Kurniawan \\ Prodi Seni Karawitan \\ Fakultas Seni Pertunjukan ISBI Bandung \\ Jalan Buahbatu No. 212 Bandung 40265 \\ budi_kurniawan@isbi.ac.id
}

\begin{abstract}
Industrial Design Act No. 31 of 2000 provides protection to any ornamental or aesthetic aspect of an article. Hence, it gives widest opportunity to people to create a creative design. On the other side, Traditional Music Instrument which is part of folklore or traditional cultural expression (TCE) in some way still give an opportunity to anyone also to add an element and or make new design inherent to instruments. A mix between public owned rights of Traditional Music Instrument and the private right of Industrial Design arise new problem in legal sense including to define an exact definition of a "novelty" element adhere in every Industrial Design application submitted. The fact that Industrial Design Office is in a passive standing when they accept a new Industrial Design's application both from a good faith's creator or even a bad faith's creator make the office could not reject that application until some one propose an objection. On the other side, legal awareness of interested parties, in this case, are traditional music instruments manufacturers who have been producing instruments for many years are still low when oppose on such problems. This article will focus on reviewing "a novelty" element adhere in every on a new application of Industrial Design submitted faced on "a not novelty" element which is arising in Traditional Music Instruments base.
\end{abstract}

Keywords : Industrial Design, Traditional Music Instrument, novelty

\section{Pendahuluan}

Dua dasawarsa pasca tergulingnya pemerintahan Orde Baru, porsi ke-wenangan Pemerintah Daerah mulai diperluas. Kewenangan hak prero-gatif Pemerintah Pusat didesentralisasikan dan didekonsetrasikan sebagai pelimpahan mandat yang beralih menjadi kewenangan pemerintah da- erah pada level Provinsi, Kabupaten, dan Kota. Kondisi tersebut memberi keleluasaan pemerintah daerah untuk mengembangkan potensi seni budaya dan kesadaran kearifan lokal - entitas yang termarginalkan pada masa Orde Baru - mulai diprioritaskan, diperhitungkan, dan didudukkan sebagai aset atau 'kekayaan' di 
daerah. Salah satunya adalah entitas alat musik tradisional.

Alat musik tradisional yang mendapat prioritas kewenangan Otonomi Daerah, berimplikasi konsekuensi logis, dengan produktivitas permintaan alat musik tradisional untuk kebutuhan pertunjukan dan media pengajaran. Eskalasi kebutuhan ini meningkatkan kuantitas produksi para pengrajin alat musik tradisional, berstimulus lahirnya bentuk kreativitas dan daya saing para pengrajin yang memberi tafsir garap atau inovasi pada produknya. Situasional tersebut menciptakan kelompok pengrajin yang konsisten mempertahankan desain yang telah melembaga atau mentradisi, dan kelompok pengrajin yang memberikan kreativitas penambahan desain fitur ornamentasi baru. Penawaran alat musik tradisional menjadi bervariasi dan semakin menyemarakkan pangsa pasar/konsumen alat musik tradisional. ${ }^{1}$

Atmosfir keberadaan pengrajin yang memberi penambahan fitur ornamentasi baru, menunjukan indikasi bahwa pada masa yang akan datang, diproyeksikan akan muncul proposisi desain-desain baru - baik proposisi dua dimensi maupun tiga dimensi - yang inheren dengan alat musik tradisional. Proposisi tersebut seperti angklung yang didaftarkan ke United Nations Educational, Scientific, and Cultural Organization (UNESCO) dan mendapat perlindungan kekayaan intelektual, sebagai warisan budaya tak benda milik Indonesia pada tahun 2010. Tidak menutup kemungkinan proposisi desain baru pada alat musik tradisional lain bernasib sama halnya angklung. Terlebih keuntungan para pengrajin sebagai pemegang hak eksklusif atas desain-desain baru, dilindungi UU No. 31 Tahun 2000 yang mengatur tentang Desain Industri, pada Pasal 1 ayat (1) sebagai berikut:

"Desain industri adalah suatu kreasi tentang bentuk, konfigurasi atau komposisi garis atau warna, atau garis dan warna, atau gabungan dari padanya yang berbentuk tiga dimensi atau dua dimensi yang memberikan kesan estetis dan dapat diwujudkan dalam pola tiga dimensi atau dua dimensi yang memberikan kesan estetis serta dapat dipakai untuk menghasilkan suatu produk, barang, komoditas industri, kerajinan tangan."

Kreasi benda tiga dimensi ataubenda yang memiliki ruang (meliputi dimensi panjang, lebar, dan tinggi, seperti patung dan alat musik) dan kreasi benda dua dimensi atau benda yang tidak 
memiliki ruang (meliputi dimensi panjang dan lebar seperti komposisi garis dan warna ataupun gabungan dari padanya) mendapat perlindungan hukum untuk didaftarkan sebagai produk desain industri. ${ }^{2}$ Manifestasi pendaftaran alat musik tradisional yang dihakpatenkan ke dalam produk desain industri, gambaran contoh kasusnya, adalah kendang sebagai instrumen musik komunal, penemunya tidak diketahui (no name), telah mentradisi melewati perjalanan ruang dan waktu selama berabad-abad. Kendati kepemilikan kendang adalah komunal, ternyata menyisakan kesempatan untuk diklaim sebagai produk desain industri dan menjadi hak eksklusif pengrajin tertentu. Contoh kendang yang merepotkan saat dibawa, tetapi menjadi praktis setelah dilengkapi pegangan tangan oleh pengrajin. Pegangan tangan yang inheren dengan kendang itulah, yang diklasifikasikan sebagai fitur produk desain industri dan menjadi hak eksklusif pengrajin yang mendaftarkannya. Begitu pula dengan desain industri produk dua dimensi pada alat musik tradisional, seperti suling yang diberi lukisan motif kartun agar anak kecil tertarik mempelajarinya. Lukisan yang inheren dengan suling itulah, sebagai fitur produk desain industri dan menjadi hak ekslusif pengrajin yang mendaftarkannya.

Entitas desain yang dianggap baru menyisakan permasalahan subtansi batasan yang jelas dan tegas sebagai kategorisasi desain 'baru' pada produk dua dimensi atau tiga dimensi yang inheren pada alat musik tradisional. Pengrajin dapat mengklaim dan mendaftarkan setiap desain sebagai desain 'baru,' ke Direktorat Jenderal Hak Kekayaan Intelektual (DJ HKI) tanpa melalui pemeriksaan substantif. Kecuali selama proses pengumuman ( 3 bulan) ada sanggahan dari pihak ketiga yang dirugikan dengan pendaftaran tersebut, misal ada kemiripan atau kesamaan dengan desain miliknya, maka DJ HKI melaksanakan pemeriksaan substantif. Tanpa sanggahan pihak ketiga tidak akan ada pemeriksaan substantif, sehingga desain yang diajukan tidak diperiksa unsur 'kebaruannya.' Hal itu menimbulkan probabilitas terjadi kesamaan atau kemiripan desain dengan pihak lain di kemudian hari. ${ }^{3}$

Tulisan ini berusaha mencari jawaban atas pertanyaan tentang asas hukum pengertian desain 'baru' dalam proposisi dua dimensi dan 
tiga dimensi yang dilekatkan/ ditempelkan pada alat musik tradisional. Kajian ini berpretensi menghasilkan kesepahaman seniman atau pengrajin mengenai proposisi desain 'baru' yang didaftarkan ke DJ HKI, termasuk bila ternyata desain tersebut telah didaftarkan pihak lain, maka hal-hal apa saja yang tidak boleh dan boleh dilakukan sesuai dengan hukum.

\section{A. Metode}

Tulisan ini merupakan kajian hukum normatif yaitu hukum kepustakaan yang dikenal dalam istilah legal research instruction (Soekanto, 2010:23). Pada kajian hukum normatif, bahan pustaka merupakan data fundamental yang dalam penelitian diklasifikasikan sebagai data sekunder. Melalui tulisan ini, penulis berusaha mencari asas hukum atas unsur baru pada Desain Industri yang inheren melekat pada alat musik tradisional yang diajukan demi memperoleh kepastian hukum bagi semua pihak. Selain bersumber UU Desain Industri yang berlaku, juga konvensi-konvensi internasional yang telah diratifikasi, termasuk putusan atas kasus Desain Industri di Pengadilan Niaga di Indonesia, akan menjadi bahan kajian untuk mengkaji masalah, demi menjelaskan atas unsur "baru" pada Desain Industri. Kajian ini akan menunjukan konsistensi penafsiran asas hukum atas unsur baru pada Desain Industri baik pada tingkatan kantor DJ HKI hingga ruang-ruang pengadilan. Mengingat variable kedua dari tulisan ini adalah alat musik tradisional, maka Undang-undang Hak Cipta juga menjadi bahan untuk mengkaji, khususnya tentang pasal yang mengatur Ekspresi Budaya Tradisional (EBT) atau dikenal pula dengan istilah folklor.

\section{B. Pembahasan}

Pembahasan menyoroti dinamika kemunculan undang-undang yang melindungi Desain Industri pada tataran global. Hal ini berstimulus terhadap kemunculan perundang-undangan desain industri di Indonesia. Namun pada pelaksanaannya kerap terjadi problematika dalam penerapnya.

\section{Alat Musik Tradisional Sui Generis Ekspresi Budaya Tradi- sional (EBT)}

UU No. 28 Tahun 2014 tentang Hak Cipta, termasuk UU Desain Industri, menganut haluan rezim HKI yang diatur World Trade Organization (WTO) sebagai organisa- 
si internasional yang dibentuk karena dorongan kuat kepentingan negara-negara maju. Indonesia menjadi original member WTO sejak tahun 1995. WTO telah membuat kesepakatan yang secara khusus mengatur HKI yang termaktub dalam Agreement on Trade Related Aspects of Intellectual Property Rights (TRIPs). Namun pada praktiknya WTO dengan penerapan TRIPs, terlalu konvensional dan tidak mampu mewadahi keunikan yang begitu luas dari Ekspresi Budaya Tradisional (EBT) dengan segala adaptasi yang muncul. ${ }^{4}$

Hal itu menjadi perhatian World Intellectual Property Organization (WIPO) dan UNESCO sebagai badan Perserikatan Bangsa-Bangsa (PBB) untuk memperjuangkan entitas Ekspresi Budaya Tradisional (EBT). Ratusan negara anggota PBB - baik negara miskin, menengah, dan maju - dengan keanekaragaman ras, suku, dan puluhan ribu EBT ditangani WIPO dan UNESCO, termasuk entitas musik tradisional. Direktorat Jendral HKI Kementerian Hukum dan Hak Asasi Manusia Republik Indonesia melalui Konferensi Pres tanggal 31 Agustus 2009 menyatakan bahwa budayabudaya tradisional merupakan sistem yang berbeda dengan sistem HKI yang modern. Oleh karena itu, alat musik tradisional sebagai bagian dari EBT bukanlah sui generis Hak Cipta melainkan sui generis EBT yang pengaturannya banyak dibuat oleh WIPO dan UNESCO.

Pemerintah Indonesia mengisi kekosongan hukum sembari menunggu disahkannya undang-undang yang khusus mengatur EBT/ folklor - urgen karena kekayaan EBT di Indonesia yang melimpah - mewadahi permasalahan EBT melalui UU No. 28 Tahun 2014 tentang Hak Cipta, pasal 38 yang terdiri 3 (tiga) ayat, dikutip sebagai berikut:

Pasal 38

1) Hak Cipta atas Ekspresi Budaya Tradisional dipegang oleh Negara.

2) Negara wajib menginventarisasi, menjaga, dan memelihara Ekspresi Budaya Tradisional sebagaimana dimaksud pada ayat (1).

3) Penggunaan Ekspresi Budaya Tradisional sebagaimana dimaksud pada ayat (1) harus memperhatikan nilai-nilai yang hidup dalam masyarakat pengembannya.

Panduan untuk pengimplementasian entitas EBT diperjalas Pemerintah Indonesia, melalui Penjelasan UU No. 28 Tahun 2014 Pasal 38 Ayat 1, sebagai berikut: 
Yang dimaksud dengan "ekspresi budaya tradisional" mencakup salah satu atau kombinasi bentuk ekspresi sebagai berikut:

a. verbal tekstual, baik lisan maupun tulisan, yang berbentuk prosa maupun puisi, dalam berbagai tema dan kandungan isi pesan, yang dapat berupa karya sastra ataupun narasi informatif;

b. musik, mencakup antara lain vokal, instrumental, atau kombinasinya;

c. gerak, mencakup antara lain, tarian;

d. teater, mencakup antara lain, pertunjukan wayang dan sandiwara rakyat;

e. seni rupa, baik dalam bentuk dua dimensi maupun tiga dimensi yang terbuat dari berbagai macam bahan seperti kulit, kayu, bambu, logam, batu, keramik, kertas, tekstil, dan lain-lain atau kombinasinya; dan

f. upacara adat.

Sebelum Pemerintah Indonesia menerbitkan UU No. 28 Tahun 2014 tentang Hak Cipta, pada tahun 1985 WIPO dan UNESCO menerbitkan Model Provisions for National Laws on The Protection of Expression of Folklore against Illicit Exploitation and Other Prejudicial Actions (1985), yakni ketentuan hubungan Hak Kekayaan Intelektual (HKI) dengan folklore (EBT), sebagai arahan yang tidak mengikat bagi seluruh negara anggota PBB ketika menyusun hukum nasional berkenaan dengan perlindungan Folklor.

expressions of folklore diartikan sebagai: Productions consisting of characteristic elements of the traditional artistic heritage developed and maintained by a community of (name of the country) or by particular:

1. verbal expressions such as folk tales, folk poetry and riddles;

2. musical expressions, such as folk songs and instrumental music;

3. expressions by action, such as folk dances, plays and artistic forms and rituals; whether or not reduced to a material form; and

4. tangible expressions, such as: (a) productions of folk art, in particular, drawings, paintings, carvings, sculptures, pottery, terracotta, mosaic, woodwork, metalware, jewellery, basket weaving, needlework, textiles, carpets, costumes; (b) musical instruments; (c) architectural forms.

Bandingkan penjelasan Pasal 38 ayat (1) UU No. 28 Tahun 2014 yang tidak memuat secara eksplisit alat musik tradisional sebagai EBT dengan model ketentuan EBT yang dibuat WIPO \& UNESCO yang secara eksplisit 'memasukan' alat musik tradisional; disayangkan justru Pasal 10 UU No. 19 Tahun 2002 tentang Hak Cipta yang dahulu berlaku dan sekarang tidak berlaku lagi memuat 
pengertian EBT/folklor yang lebih luas.

WIPO membuat pengklasifikasian bahwa hasil ekspresi budaya tradisional (EBT) dari masyarakat asli dapat dimasukkan sebagai folklor apabila hasil ekspresi budaya tradisional tersebut memenuhi kriteria: (1) diturunkan dari generasi ke generasi baik melalui media oral maupun peniruan; (2) sebagai cerminan identitas sosial dan budaya masyarakat; (3) terdiri atas elemenelemen khas dari sebuah warisan masyarakat; (4) dibuat oleh pencipta yang tidak diketahui identitasnya dan atau oleh masyarakat dan atau oleh individu-individu yang secara komunal dianggap memiliki hak, tanggung jawab, atau ijin untuk melakukan penciptaan tersebut; (5) seringkali ciptaan tersebut tidak dibuat untuk tujuan-tujuan komersial tetapi sebagai alat untuk kepentingan relegius dan sebagai ekspresiekspresi budaya; dan (6) secara terus-menerus tumbuh berkembang dan dikreasikan ulang oleh masyarakat (WIPO Intellectual Property and Traditional Cultural Expressions/Folklore, Booklet No. 1: 5). Keenam ciri tersebut menjadi tolok ukur apakah suatu kreasi ciptaan yang telah ada dapat dikategorikan sebagai folklor atau tidak.

Pada kondisi seperti apa sebuah alat musik tradisional dapat disebut sebagai bentuk asli atau orisinal dari bagian EBT? Jawabannya ditemukan pada sumber dokumentasi sejarah berupa foto dan lukisan, gambar-gambar, tulisantulisan, relief candi, barang antik di museum, kesaksian para ahli musik tradisi, yang semuanya merujuk keyakinan pada bentuk/konfigurasi dan komposisi pola warna dan garis yang mewujud tiga dimensi atau dua dimensi atau gabungan keduanya. Semua dokumentasi merujuk pada desain-desain alat musik tradisional yang telah dikenal sejak lampau dan turun-temurun sebagai bagian Ekspresi Budaya Tradisional.

WIPO memasukkan alat musik tradisional sebagai tangible expression atau ekspresi budaya benda dari masyarakat tradisional pengusung (sebagai implikasi dari makna tradisional) yang secara turun-menurun menjaga, memelihara, dan mengembangkan bentuk, motif, gaya, model fitur tiga dimensi maupun dua dimensi yang melekat pada alat musik tradisional. Masyarakat tradisional yang menjadi pen- 
dukung setia dianggap paling berhak mengeksploitasi benda tadi. Perkembangan yang dinamis dari desain alat musik tradisional memungkinkan muncul turunan baru ataupun tambahan elemen baru yang dikembangkan oleh masyarakat itu sendiri, dan itu dapat dilindungi secara HKI. Walau demikian perlindungannya hanya sebatas pada turunan atau tambahan baru dari sebuah EBT. Pada kajian tertulisnya WIPO menyatakan.

In a dynamic and creative context, it is often difficult to know what constitutes independent creation. Yet, under current copyright law, a contemporary expression derived from or inspired by preexisting traditional materials and which incorporates new elements can often be sufficiently original to qualify as a copyright work and thus benefit from copyright protection. However, the protection afforded to such "derivative" works vests only in their new material or aspects (WIPO Intellectual Property and Genetic Resources, Traditional Knowledge and Traditional Cultural Expressions Booklet:31).

Dengan dasar itulah, maka EBT dan produk turunannya dimasukkan dalam Pasal 38 UU No. 28 Tahun 2014 tentang Hak Cipta. Namun sayangnya UU No. 31 Tahun 2000 tentang Desain Industri tidak memasukkan perlindungan EBT menyangkut kreasi tiga dimensi seperti desain baru yang bersumber atau berakar dari desain-desain EBT khususnya seperti alat musik tradisional. Seharusnya hal itu diatur dalam UU Desain Industri bukan pada UU Hak Cipta saja. Sebagai contoh, alat musik tradisional akan masuk kepada kelompok EBT/folklor menurut Pasal 38 UU Hak Cipta, tetapi bila kemudian ada pendesain membuat desain baru yang melekat pada alat musik tradisional dan ia mau mendaftarkannya secara Desain Industri maka tidak muncul atau setidaknya tidak ada dasar hukum yang secara eksplisit tegas menyatakan desain seperti demikian masuk dalam UU Desain Industri. Acuannya bisa ke WIPO's guidelines yang dibuat oleh intergovernmental commitee seperti berikut ini (Intergovernmental Committee on Intellectual Property and Genetic Resources, Traditional Knowledge and Folklore: 19) :

Much of the analysis above with respect to literary and artistic productions is relevant also to designs. Traditional designs that are more contemporary adaptations of earlier traditional designs would qualify for protection as industrial designs and could be registered as such, and other 
documents cited examples from China and Kazakhstan. 25 On the other hand, underlying designs from the distant past and copies of them would not be protected. There is, however, less experience with the protection of traditional designs.

\section{Desain Industri di Indonesia}

Upaya negara-negara memuliakan hasil kreativitas intelektual yang diaktualisasikan ke dalam desain yang dilindungi, baik oleh WIPO maupun WTO yang menerbitkan guidelines dan ketentuan yang melindungi HKI, menyebabkan Indonesia yang menjadi anggota kedua organisasi tersebut, menerapkan guidelines dan ketentuan yang dikeluarkan WTO dan WIPO secara bersamaan atau saling melengkapi. Meskipun demikian, UU Desain Industri Indonesia lebih dominan dipengaruhi guidelines dari WTO. Hal ini nampak pada bagian Menimbang dan Mengingat pada UU No. 31 Tahun 2000 tentang Desain Industri, yang tegas secara eksplisit menyatakan aturan TRIP's sebagai sumber penyusunan UU Desain Industri.

Peraturan tentang Desain Industri muncul akibat kebutuhan perlindungan terhadap elemen-elemen desain yang bersifat baru meskipun fitur elemen tersebut tidak memberikan fungsi yang signifikan, tetapi tetap mendapatkan perlindungan - sebagai hasil dari aktivitas desain yang diterapkan dalam dunia industri. Hal itu disebabkan desain suatu benda dapat memberikan pengaruh luar biasa kepada konsumen dalam menentukan benda industri tersebut akan dibeli atau tidak dibeli (selain tentunya konsumen juga melihat fungsi benda yang bersangkutan dan harga).

Pada level produksi - setelah desain baru terdaftar sebagai Desain Industri - setiap produsen berusaha menjadi pihak yang memonopoli dan mencegah produsen lain meniru desainnya. Hak monopoli ini dilindungi secara eksklusif, antara lain hak yang melarang siapa saja yang sengaja dan tanpa persetujuan, membuat, menggunakan, menjual, mengimpor, mengekspor, dan/atau mengedarkan barang yang telah diberi hak Desain Industri. Hak eksklusif ini termasuk hak untuk mengajukan gugatan perdata dan/ atau pidana terhadap yang melanggar hak Desain Industri yang telah tedaftar.

Sistem pendaftaran Desain Industri menganut sistem first to file (yang mirip pendekatan Paten), artinya produsen yang pertama kali mengajukan permohonan akan di- 
anggap sebagai pemegang Desain Industri sepanjang seluruh persyaratan telah dipenuhi. Pengajuan permohonan yang memenuhi persyaratan akan memperoleh tanggal penerimaan untuk segera diproses, diperiksa bahwa permohonan tersebut laik untuk diumumkan. Pemeriksaan administratif meliputi pemeriksaan fisik, formalitas, dan kejelasan pengungkapan Desain Industri. Pengumuman kepada publik diberi batas waktu tiga bulan, bertujuan memberi kesempatan bagi masyarakat yang keberatan terhadap desain tersebut, berdasar alasan substantif sebagaimana diatur dalam Pasal 2 tentang kebaruan desain dan/atau alasan Pasal 4 UU Desain Industri tentang larangan desain yang bertentangan dengan peraturan perundangan, ketertiban umum, agama, dan kesusilaan. Apabila ditemukan keberatan dari masyarakat, maka berakibat terjadinya pemeriksaan substantif terhadap desain yang dimohonkan dengan batas waktu selama enam bulan, yang hasilnya dapat berujung permohonan desain itu diterima atau ditolak.

Desain yang diterima dan disetujui memperoleh sertifikat Desain Industri dan berlaku untuk jangka waktu 10 tahun terhitung sejak tanggal penerimaan. Pem- berian sertifikat Desain Industri tidak serta merta menjadikan desain tadi tidak dapat dimintakan pembatalannya melalui pengadilan niaga. Di Indonesia sertifikat Desain Industri yang telah didaftarkan dapat dibatalkan melalui persidangan Pengadilan Niaga sepanjang pihak lawan dapat membuktikan klaimnya, bahwa desain yang terdaftar diperoleh dengan itikad buruk ataupun dengan dasar perbuatan melawan hukum.

Mengingat perkembangan desain yang melekat pada suatu benda tampil dinamis di dunia industri, maka jangka waktu perlindungan Desain Industri hanya 10 tahun dan tidak dapat diperpanjang lagi. Setelah melampaui jangka waktu tersebut, desain yang terdaftar menjadi milik umum, dan semua pihak dapat menggunakan Desain Industri yang telah kadaluwarsa tersebut. Bahkan dimungkinkan lahir pengembangan fitur baru di mana menjelma sebagai elemen desain baru. Hal ini memberikan kesempatan bahwa kepada pengrajin melalui proses kreativitas tanpa batas.

\section{Desain Baru dalam Kerangka Desain Industri}

Salah satu syarat sebuah desain dapat didaftarkan adalah unsur 
kebaruan yang inheren dan terintegrasi dalam produk industri tersebut. Hal itu termaktub pada Pasal 2 ayat (1) dalam UU Desain Industri:

Ayat (1) "Hak Desain Industri diberikan untuk desain yang baru;"dan ayat (2) "Desain Industri dianggap baru apabila pada tanggal penerimaan Permohonan Desain Industri tersebut tidak sama dengan pengungkapan yang telah ada sebelumnya."

Pasal di atas menunjukan entitas paradoks yang menjadi landasan pengajuan hak atas suatu desain industri. Entitas tersebut adalah 'kebaruan' dan 'sesuatu yang telah ada sebelumnya.' Artinya harus ditemukan syarat entitas pembanding yang dapat menunjukan bahwa pengajuan desain tersebut teridentifikasi berbeda dengan desain yang telah ada sebelumnya.

\section{Tentang Desain Baru}

Desain baru dalam UU Desain Industri bersifat absolut, tetapi bertendensi relatif subyektif. Mengapa demikian? Dikatakan absolut, karena desain yang ditawarkan harus 'baru' atau belum pernah ada sebelumnya, hal itu harus ditunjukkan pada tanggal permohonan desain itu diterima. Adapun sifat relatif subyektif dikarenakan penilaian subjektif dapat terjadi ketika teridentifikasi desain yang 'tidak sama' tetapi memiliki 'kemiripan'. Mengapa demikian? Tafsiran kata "sama" secara absolut diartikan sebagai 'sama persis' atau kesamaan dengan tingkat persentase $100 \%$ dari desain yang telah ada. Begitu pula dengan tafsiran proposisi 'tidak sama' yang berarti sebagai 'tidak sama persis' dengan desain yang ada sebelumnya (kemungkinan kesamaannya tidak $100 \%)$.

Persoalan sama atau tidak sama, akan mudah dinyatakan pada suatu desain yang sederhana, tetapi bila menyangkut desain yang rumit dan kompleks akan sulit disimpulkan bahwa desain itu adalah 'sama' atau 'tidak sama' tanpa harus menyangkut-pautkan dengan aturan Paten. Seperti desain mesin yang dilengkapi komponen yang inheren melekat di dalamnya, apalagi disertai gabungan komposisi dua dimensi yang melekat, dipastikan semakin subyektif kesan 'sama' atau 'tidak sama' tersebut. Aturan TRIPs Section 4: Industrial Designs, Article 25 Requirement for Protection, menyatakan:

Member shall provide for the protection of independently created industrial design that are new or original. Members may provide that design are 
not new or orginal if they do not significantly differ from known designs or combination of known design features. Members may provide that such protection shall not extend to design dictated essentially by technical or functional considerations.

Aturan TRIPs di atas begitu jelas menyatakan bahwa desain dianggap tidak baru apabila desain dimaksud tidak berbeda secara signifikan dengan desain yang telah dikenal atau merupakan kombinasi dari fitur desain yang telah ada. Namun kembali lagi, definisi 'tidak signifikan' menjadi hal yang bersifat relatif subyektif yang diinterpretasi berbeda-berbeda oleh setiap individu.

Permasalahan kajian unik di Indonesia tentang rumitnya penyusunan asas kebaruan dalam perkara pembatalan hak desain industri 'Mesin Gergaji STIHL' dimana telah terjadi ketidakpastian hukum dalam putusan Pengadilan Niaga dan Mahkamah Agung yang perkaranya berlanjut hingga tingkat Peninjauan Kembali (PK). Pada pengadilan tingkat pertama, di Pengadilan Niaga Jakarta diputuskan tafsiran bahwa kata 'tidaksama' diartikan 'tidak sama secara substansial.' Selanjutnya pada tingkat kasasi diputuskan berdasarkan tafsiran bahwa kata "tidak sama" diartikan "tidak identik" (tidak sama persis), dan terakhir pada tingkat Peninjauan Kembali, putusan hakim kembali menggunakan dasar pertimbangan sebagaimana pada putusan Pengadilan Niaga, yaitu memutuskan berdasarkan tafsiran bahwa kata 'tidak sama' diartikan 'tidak sama secara substansial.' Kondisi demikian menimbulkan ketidakpastian hukum mengenai 'batas kepemilikan' hak desain industri yang pada dasarnya ditentukan oleh 'kebaruan' Desain Industri (Citrawinda, 2013:18).

Permasalahan dalam mendefinisikan proposisi "tidak sama secara substansial" berarti desain yang disanggah harus 'tidak sama pada pokoknya' (secara substantif) dengan desain yang telah ada. Metode pendekatan 'tidak sama secara substansial' ini pun sebenarnya dapat dilakukan dengan dua bentuk pendekatan, yakni pendekatan Hak Cipta dan pendekatan Merek, tetapi sayang kedua pendekatan ini berbeda atau setidaknya sulit diterapkan pada Desain Industri. Bahkan pendekatan 'sama pada pokoknya' ditinggalkan dalam UU No. 28 Tahun 2014 tentang Hak Cipta. Padahal sebelumnya dalam Bagian Penjelasan Pasal 15 UU No.19 Tahun 2002 tentang Hak Cipta yang sudah tidak 
berlaku terdapat keterangan yang menarik:

Pembatasan ini perlu dilakukan karena ukuran kuantitatif untuk menentukan pelanggaran Hak Cipta sulit diterapkan. Dalam hal ini akan lebih tepat apabila penentuan pelanggaran Hak Cipta didasarkan pada ukuran kualitatif. Misalnya, pengambilan bagian yang paling substansial dan khas yang menjadi ciri dari Ciptaan, meskipun pemakaian itu kurang dari $10 \%$. Pemakaian seperti itu secara substantif merupakan pelanggaran Hak Cipta.

Nampaknya penyusun undang-undang Hak Cipta yang baru lebih fokus pada pelanggaran Hak Cipta dalam bentuk penggandaan dan penggunaan tanpa ijin suatu ciptaan, bukan lagi pada penyelesaian sengketa "kemiripan" suatu ciptaan. Oleh karena itu, Majelis Hakim Pengadilan Niaga yang memberi tafsiran kasus per kasus "kesamaan pada pokoknya”. Sedangkan dalam pendekatan Merek, yang disebut Merek yang memiliki "kesamaan pada pokoknya" dengan Merek lain adalah apabila tidak ada daya pembeda dengan Merek yang sudah ada dan terkenal. Tapi ini lebih mudah diterapkan karena Merek memfokuskan pada bentuk dua dimensi saja, tidak seperti Desain Industri yang bisa menggabungkan dua dimensi dengan tiga dimensi. WIPO pun menyatakan dimungkinkan adanya desain baru lain yang dibuat oleh pendesain lain tetapi memiliki fungsi dan kegunaan yang sama:

Design protection only applies to such articles or products as embody or reproduce the protected design. Protection does not, therefore, prevent other manufacturers from producing or dealing in similar articles fulfilling the same utilitarian function, provided that such substitute articles do not embody or reproduce the protected design (WIPO Intellectual Property Handbook: Policy, Law and Use, 2016:114).

Ada baiknya pemikiran seperti UU No. 28 Tahun 2014 tentang Hak Cipta yang tidak lagi "mengurusi" kemiripan atas sebuah ciptaan dengan ciptaan yang lain, digunakan dalam UU Desain Industri. Apalagi dalam Desain Industri ditemukan kelemahan soal pemeriksaan substantif. Penelitian yang telah dilakukan menunjukkan bahwa salah satu kelemahan dari UU Desain Industri tertuju pada ketentuan Pasal 29 ayat (1) yang tidak menerapkan pemeriksaan substantif terhadap setiap permohonan yang diajukan ke Ditjen HKI. Akibat kelemahan sistem tersebut, di antaranya telah dimanfaatkan oleh pihak-pihak yang beritikad tidak baik (bad faith) 
untuk mendapat sertifikat Desain Industri tanpa adanya pemeriksaan substantif. Potensi tersebut dapat disalahgunakan untuk memonopoli pemasaran secara tidak sehat, dalam rangka mendapat keuntungan sebanyak-banyaknya tetapi berlawanan dengan norma-norma dan etika hukum (Ansori Sinungan, 2011: 29).

\section{Tentang Pengungkapan Sebelum-} nya

Seperti telah disebut sebelumnya, pada Pasal 2 Ayat (2) dinyatakan "Desain Industri dianggap baru apabila pada tanggal penerimaan Permohonan Desain Industri tersebut tidak sama dengan pengungkapan yang telah ada sebelumnya." Definisi pengungkapan yang telah ada sebelumnya diatur dalam Pasal 3 dan 4 pada UU Desain Industri, yang pada pokoknya adalah pengungkapan Desain Industri yang menyatakan: (1) sebelum Tanggal penerimaan; atau (2) sebelum Tanggal prioritas apabila permohonan diajukan dengan hak prioritas telah diumumkan atau digunakan di Indonesia atau di luar Indonesia.

Suatu Desain Industri tidak dianggap telah diumumkan apabila dalam jangka waktu paling lama 6 (enam) bulan sebelum tanggal penerimaannya, Desain Industri tersebut:

1. Telah dipertunjukkan dalam suatu pameran nasional ataupun internasional di Indonesia atau di luar negeri yang resmi atau diakui sebagai resmi; atau

2. Telah digunakan di Indonesia oleh Pendesain dalam rangka percobaan dengan tujuan pendidikan, penelitian, atau pengembangan.

\section{Kesimpulan}

Sebuah fitur ornamentasi baru berbentuk dua dimensi atau tiga dimensi yang melekat pada benda dari sebuah desain alat musik tradisional memungkinkan diidentifikasi dan diterima sebagai unsur kreativitas yang 'baru' dan didaftarkan ke dalam Desain Industri sepanjang memenuhi Pasal 2, 3 dan 4 pada UU Desain Industri. Fitur desain semacam itu, secara nyata berbeda dengan alat musik tradisional yang sebelumnya telah ada dengan perbedaan persentase adalah $100 \%$.

Begitu pula jika suatu desain benda baru yang merupakan adaptasi dan turunan dari sebuah alat musik tradisional memungkinkan untuk dapat dianggap baru dan didaftarkan sebagai Desain Industri 
sepanjang memenuhi Pasal 2, 3, dan 4 UU fitur desain semacam itu, misal ketidakmiripnya kurang dari persentase $100 \%$. Kemungkinan tersebut disebabkan unsur kebaruan atau novelty yang dipersyaratkan dalam sebuah desain hingga saat ini masih dalam perdebatan.

Walau demikian kiranya putusan Peninjauan Kembali (PK) Mahkamah Agung (MA) pada perkara desain "Mesin Gergaji STHIL", dimana putusan Hakim Agung MA kembali menggunakan dasar pertimbangan sebagaimana pada putusan Pengadilan Niaga, yang memutuskan perkara berdasar tafsiran bahwa kata "tidak sama" diartikan "tidak sama secara substansial" dapat dipertimbangkan untuk digunakan. Selain karena putusan PK adalah putusan akhir yang berkekuatan hukum tetap, maka sepatutnyalah kita menghargai doktrin MA itu. Walaupun demikian, penggunaannya haruslah hati-hati bila perlu melibatkan banyak ahli desain atau asosiasi para pendesain untuk menentukan soal kesamaan substantif ini.

\section{Catatan Pembaca}

${ }^{1}$ Indonesia sebagai negara yang kaya akan seni budaya tercatat memiliki puluhan alat musik tradisional, beberapa di antaranya:angklung, anak becing, alosu, atowo, arumba, aramba, basa-basi, babun, calung, cungklik, doli-doli, dog-dog, druridana, faritia, floit, foi mere, gamelan, garantung, gerdek, gonrang, hapetan, kecapi,Keloko, Kere-kere Galang, keso-keso, Kinu, Kledi,Kolintang, lembang, nafiri, popondi,rebab,Sampek, Sasando, seluang, Siter atau Celempung, Talindo, Talempok Pacik, Tifa, Toto Buang

${ }^{2}$ Desain bukanlah sekedar desain tanpa makna, desain atas sebuah benda biasanya dirancang karena adanya fungsi yang kemudian menemukan bentuknya. Sebuah panci untuk memanaskan air membutuhkan pegangan isolator, maka muculah desain panci dengan pegangan terbuat dari kayu misalnya. Semua kain tentu tidak akan menarik hati bila polos tanpa motif, maka kemudian munculah ribuan motif kain penuh komposisi corak dan warna yang kemudian terdaftar sebagai Desain Industri demi menarik hati konsumen.

${ }^{3}$ Sanggahan pihak ketiga bergantung sepenuhnya pada kesadaran hukum para pengrajin alat musik tradisional. Sayangnya, jika memperhatikan kelompok usaha yang terdapat di Indonesia ternyata lebih banyak kelompok usaha kecil dan menengah saja. Dan mereka belum memiliki kesadaran terhadap "Hak Kekayaan Intelektual" atau HKI yang baik, memadai, dan dapat dikatakan "budaya HKI" belum menjadi bagian dalam masyarakat Indonesia dan para pelaku bisnis maka UU Desai Industri ini perlu mengakomodasikan pendekatan Hak Cipta (Insan Budi Maulana:20)

${ }^{4}$ WIPO Intellectual Property and Genetic

Resources, Traditional Knowledge and Traditional Cultural Expressions Booklet : 36)

\section{Sumber Pustaka}

Maulana, Budi Insan. 2010. Desain Industri Teori dan Praktik di Indonesia. Bandung: Citra Aditiya Bakti.

Sinungan, Ansori. 2011. Perlindungan Desain Industri Tantangan dan Hambatan Dalam Praktiknya di Indonesia. Bandung: Alumni. 
Soekanto, Soerjono. 2010. Penelitian Hukum Normatif Suatu Tinjuan Singkat. Jakarta: Rajawali Pers.

\section{Sumber Internet}

Citrawinda,Cita.2013. "Naskah Akademik Rancangan Undang-undang Tentang Desain Industri." Pusat Perencanaan Pembangunan Hukum Nasional Badan Pembinaan Hukum Nasional Kemenhuk Ham.

Melaluihttp://www.bphn.go.i d/data/documents/naskah_a kademik_ruu_tentang_desain _industri.pdf [24/10/2016]

WIPO. 2004. "WIPO Intellectual Property Handbook: Policy, Law and Use WIPO 2004 Second Edition Reprinted 2008. Melalui http: //www.wipo.int/edocs/pubd ocs/en/intproperty/489/wip o_pub_489.pdf.[13/11/2016]
2008. "Intergovernmental Committee on Intellectual Property and Genetic Resources, Traditional Knowledge and FolkloreThirteenth Session Geneva." Melaluihttp:/ / www.wipo.int/ edocs/mdocs/tk/en/wipo_grt kf_ic_13/wipo_grtkf_ic_13_5_ b_rev.pdf[13/11/2016]

.2011. "WIPO Intellectual Property and Traditional Cultural Expressions/ Folklore." Booklet No.1, World Intellectual Property Organization (WIPO) Publication No. 913 (E). Melalui www.wipo.int/edocs/pubdoc s/en/.../wipo_pub_catalog_2 011.pdf $[21 / 11 / 2010]$.

- 2015."Intellectual Property and Genetic Resources, Traditional Knowledge and Traditional Cultural Expressions Booklet."Melaluihttp://www.wipo.int Ledocs/pubdocs/en/tk/933/wi po_pub_933.pdf $[13 / 11 / 2016]$ 